\title{
Vertical transmission of Trypanosoma cruzi in the Province of Choapa, IV Region, Chile. Preliminary Report (2005-2008)
}

\author{
Werner $\mathrm{Apt}^{1}{ }^{*}$, Inés Zulantay ${ }^{*}$, Aldo Solari², Sylvia Ortiz², David Oddo ${ }^{3}$, Gabriela Corral ${ }^{4}$, \\ Carine Truyens ${ }^{5}$ and Yves Carlier ${ }^{5}$ \\ ${ }^{1}$ Laboratorio de Parasitología Básico-Clínico. Programa de Biología Celular y Molecular. Instituto de Ciencias Biomédicas. Facultad de Medicina. Universidad de Chile. \\ ${ }^{2}$ Laboratorio de Parasitología Molecular. Programa de Biología Celular y Molecular. Instituto de Ciencias Biomédicas. Facultad de Medicina. Universidad de Chile. \\ ${ }^{3}$ Centro del Cáncer. Pontificia Universidad Católica de Chile. \\ ${ }^{4}$ Hospital de Illapel. Servicio de Salud Coquimbo. IV Región, Chile. \\ ${ }^{5}$ Laboratorio de Parasitología. Facultad de Medicina. Universidad Libre de Bruselas. Bélgica.
}

\section{DEDICATION}

The group of doctors who finished their basic studies in 1962 in the Facultad de Medicina of the Universidad de Chile will never forget the official reception we received when we began the program in March, 1955. It was our first day in the Faculty, and we were received in the Anatomy Auditorium by Dr. Gustavo Hoecker. We soon had him as a professor in the first year Biology course, and in meetings on Saturday afternoons in Borgoño 1470, the site of the former Parasitology Hall of Dr. Amador Neghme. Years later some of us joined forces with Dr. Hoecker in research projects on Chagas disease in which he led the group. We took many field trips to the different endemic areas of the IV Region; Tulahuén, Río Hurtado, El Palqui and Huatulame, among others. We left early in the morning and usually returned late at night. In these interactions I got to know the real Dr. Hoecker; intelligent, lively, discerning and with a great group spirit. When my class of 1962 celebrated our 40th year as doctors in June, 2002, we did so with a solemn ceremony in the Facultad de Medicina, in the same auditorium where he received us on our first day of classes. In this ceremony we gave recognition to two professors, Gustavo Hoecker and Carlos Oberti (Histology Professor), which faithfully reflected the opinion of his former students. Dr. Hoecker is no longer with us, but his spirit is. In modest homage to him, we dedicate our most recent research on congenital Chagas disease, a subject which united us on more than one occasion.

DR. WERNER APT BARUCH Full Professor Facultad de Medicina, Universidad de Chile

\begin{abstract}
Congenital Chagas disease acquired special importance in Chile after the certification of the control of Triatoma infestans and transmission by blood donors affected with Trypanosoma cruzi. In order to establish adequate protocols for intervention and control in infected mother-neonate pairs in endemic zones of Chagas disease, we present partial results (2005-2008) of a pilot project which is being carried out in the Province of Choapa, IV Region, Chile, whose objectives are: determine the current prevalence of the disease in pregnant women, estimate the incidence of vertical transmission of $T$. cruzi to newborns, determine the lineages of the parasite present in mothers who do and do not transmit the disease, determine the prevalence of Chagas disease in maternal grandmothers of neonates and study placental histopathology. Preliminary results indicated that in this study period, $3.7 \%$ of the women who gave birth in the Province have Chagas disease and $2.5 \%$ of their newborns were infected. The most frequent $T$. cruzi genotypes found in mothers studied during pregnancy were TCI and TCIId, either alone or in mixed infections. A high percentage $(74.3 \%)$ of the grandmothers studied was infected with the parasite. In 29 placentas from mothers with Chagas disease we observed edema, necrosis, fibrinoid deposits and slight lymphoplasmocyte infiltration. In three placentas we found erythroblastosis and in one of them amastigote forms of $T$. cruzi; this was one of the cases of congenital infection. The evaluation of the diagnostic and control protocols generated will allow us to determine if it has been possible to modify the natural history of vertical transmission of T. cruzi in Chile.
\end{abstract}

Key terms: Congenital Chagas disease, Province of Choapa, multidisciplinary study.

\section{INTRODUCTION}

The IV Region of Coquimbo is located between $29^{\circ} 02^{\prime}$ and $32^{\circ} 16^{\prime} \mathrm{S}$ in the area of transverse valleys of Chile; it is divided into the Provinces of Elqui, Limarí and Choapa. It has three principal geographical features; the Andes Range, the complex formed by the Coast Range and Andes foothills, and flat coastal areas. Its climate is semi-arid or steppe, with a shrubby vegetation dominated by Acacia spp. (Benítez,
1994). It has an area of $40,580 \mathrm{~km}^{2}$ and a population of 603,210 , of which $21.9 \%$ are rural (INE, 2003).

Some rural areas of the IV Region are still considered as zones of high Chagas endemism due to the high indices of domestic infestation (66.9\%) (Correa et al., 1984), and infection of humans (41.2\%) (Apt and Reyes, 1986), animals (41.2\%) (Rios et al., 1986) and triatomines (37.8\%) (Apt and Reyes, 1986) reported in past decades. Although in 1999 Chile was certified to have interrupted the mechanisms of 
vector transmission of Trypanosoma cruzi by Triatoma infestans and by blood bank transfusions, vertical transmission is still a public health problem (Schenone et al., 2003).

In 2005 we began a multidisciplinary study of congenital Chagas disease in the Province of Choapa, whose preliminary results we present here. Our original objectives included determining the current serological frequency of Chagas infection in pregnant women, the incidence of congenital transmission and the lineages of parasites in mothers who do and do not transmit the disease, as well as determining the percentage of infection in the maternal grandmothers of the neonates as epidemiological information and studying the characteristics of placental histopathology.

\section{MATERIAL AND METHODS}

\section{Implementation of Control Pilot Plan}

We began to apply the protocols designed for the vertical study of T. cruzi in the province of Choapa in 2006, with the collaboration of professional teams from the urban and rural health centers of the Ministry of Health and the Municipal Departments of Health, after formal training. The protocols were designed to find Chagas infection in pregnant women, study the mother-neonate pair, confirm or discount vertical transmission in newborns and/or long-term follow up, treat infected neonates and incorporate Chagasic mothers to the regular controls of chronic Chagas disease post partum for specific treatment.

\section{Study population}

The study included pregnant women from the four communities of the Province of Choapa; Los Vilos, Canela, Salamanca and Illapel, who gave birth in one of the medical centers in the period 2006-2008. Mothers whose children were born in 2005 were retrospectively tested serologically for parasites in 2006. According to the protocol, local centers requested a screening serological exam (ELISA IgG) during the first or second third of pregnancy. The confirmation of positive cases and detection of false positive reactions were performed in our laboratory or the regional laboratory ( $\mathrm{La}$ Serena Hospital, Coquimbo Health Service), by Indirect Immunofluorescence (IIF IgG). It was recommended that this information be included on the health card with which the mother is admitted to the maternity ward to give birth, thus alerting personnel to perform the study of the mother and newborn.

Conventional quantitative serological tests

IIF tests were performed according to Zulantay et al (1998). T. cruzi epimastigote forms of the Tulahuen strain were used as antigens. The diagnosis titer of IIF IgG was $1 / 20$. The ELISA test of neonates was performed in the Laboratorio de Referencia de Parasitología, Instituto de Salud Pública de Chile, ISP (Apt et al., 2008).

Study of the mother-neonate pair

Before birth, $4 \mathrm{cc}$ of venous blood was extracted from the mother; 2 cc in a tube without anticoagulant for IIFIgG and 2
$\mathrm{Cc}$ in a tube with guanidine-EDTA for the parasitological study with PCR. In the delivery room, 5 cc of blood was taken from the umbilical cord of the neonate, which was divided into $1 \mathrm{cc}$ for the direct parasitological study searching for mobile trypomastigotes of T. cruzi, 2cc for the parasitological study with PCR to detect kinetoplastic DNA of T. cruzi and 2 cc for the conventional serological study (IIF and ELISA IgG).

\section{Blood PCR}

This test was performed under conditions already described (Solari et al., 2001b, Zulantay et al., 2004). The blood sample for the PCR test was boiled for $15 \mathrm{~min}$ at $97^{\circ} \mathrm{C}$ to decatenate mini-circles from the kDNA network and stored at $4^{\circ} \mathrm{C}$. DNA extraction was performed from $200 \mu \mathrm{l}$ of the mixture and chromatographic purifications (Favorgen, Biotech Corp). The PCR components included a buffer, oligonucleotides 121 and 122, dNTP, Mg, Taq polymerase and a DNA source of template from each patient in 50 ul total volume. The PCR conditions were: an initial cycle of $98^{\circ} \mathrm{C}$ for $2 \mathrm{~min}$, a second cycle of $98^{\circ} \mathrm{C}$ for $1 \mathrm{~min}$ and $72^{\circ} \mathrm{C}$ for $2 \mathrm{~min}$; 33 cycles of $94^{\circ} \mathrm{C}$ for $1 \mathrm{~min}, 64^{\circ} \mathrm{C}$ for $1 \mathrm{~min}$ and $72^{\circ} \mathrm{C}$ for $2 \mathrm{~min}$ and a final cycle of $72^{\circ} \mathrm{C}$ for $10 \mathrm{~min}$. Later $10 \mathrm{ul}$ of the final product was electrophoresed in a $2 \%$ agarose gel for $90 \mathrm{~min}$ at 113 volts and stained with ethidium bromide. All PCR tests were performed three times, each time using negative and positive PCR controls. The presence of a $330 \mathrm{bp}$ DNA band was considered a positive test. Finally, a digital photo was taken of the gel.

\section{Genotyping of T. cruzi infecting chagasic patients}

DNA samples amplified by PCR were characterized with hybridization tests and Southern analysis using a panel of $T$. cruzi genotype-specific probes (Solari et al., 2001a). Identical membranes containing DNA samples were prepared to be hybridized with each of the six available DNA probes belonging to the subgroups TcI, TcIIb, TcIId and TcIIe circulating in Chile. The construction of the probes and their validation as a typing method is available (Veas et al., 1991; Galupo et al., 2009).

Study of Chagas infection in maternal grandmothers of newborns

After the delivery, the maternal grandmothers of babies born between 2005 and 2008 were studied serologically, either by citation to the medical centers or by a house visit.

Anatomic and pathological study of the placenta

Twenty-nine placentas of mothers with Chagas were submitted to macroscopic analysis (dimensions, weight, conformation, alterations), routine optical microscopy with hematoxiline and eosin and an immunohistochemical study with the S-ABC method using monoclonal antibodies against actin. Each placenta was photographed and then a complete serial and systematic section was performed; sections were fixed in 10\% formalin buffer (10:20:1). For the routine optical microscope study we took sections from the four quadrants, while the immunohistological study used syncyotrophoblast cells from selected sections stained with hematoxiline and eosin. 


\section{RESULTS}

Serological prevalence of Chagas infection in preganant women

There were 3778 live births in the Province of Choapa in the period 2005-2008. Serological information of the mothers was previously available for $87.6 \%, 88.3 \%$ and $77.6 \%$ of the births in the centers of Illapel, Salamanca and Los Vilos, respectively (except for the year 2005 for the Los Vilos Hospital, in which serological studies were not performed). Infection by $T$. cruzi was confirmed in 123 mothers, which represents $3.7 \%$ of the births in this period. The mean age of mothers was 32 years. Nine cases $(7.3 \%)$ were from Los Vilos, 26 (21.1\%) from Canela, 42 (34.1\%) from Illapel and 46 $(37.4 \%)$ from Salamanca.

\section{Study $f$ the mother-neonate pairs}

We performed genotyping studies of all mothers in which $T$. cruzi was found when they delivered (Solari et al., 2001a). Sixty percent of the mothers had been examined regularly as chronic Chagas cases, including clinical, serological, electrocardiographic and parasitological examinations. In addition, the evaluation of hepatic function, hematology and other exclusion factors such as pregnancy or nursing were a pre-therapy condition for specific treatment. We were able to perform a study at birth and serological and parasitological follow-up on 80 of the 123 children of mothers with Chagas disease who gave birth in the years 2005-2008. Thirty three of the 43 chagasic mothers not included in this investigation correspond to mother-child pairs of 2005 on whom we have only performed a retrospective study. Congenital transmission was confirmed in two cases, which gives a preliminary transmission index of $2.5 \%$, with $95 \%$ confidence limits of $0.3 \%$ and $8.7 \%$. The other cases not examined included babies who are still less than a year old, deceased neonates, mothers who did not agree to participate in the study and families who moved out of the area or gave their child in adoption.

\section{Study of maternal grandmothers of newborns}

We investigated infection of T. cruzi in 70 of the mothers of the 123 women in the study who were found to have Chagas disease (maternal grandmothers of neonates). We found that $74.3 \%$ (95\% confidence limits $66.4 \%$ and $84 \%$ ) were infected with the parasite, and $53 \%$ of those did not know they were infected (95\% confidence limits $39.5 \%$ and $67.8 \%$ ). The age range of the grandmothers was from 40 to 82 years, with a mean of 62 years.

Genotyping of mothers infected with T. cruzi

The preliminary evaluation of T.cruzi genotypes infecting chronic mothers provided epidemiological data from 20 persons. The most frequent T.cruzi genotypes were TCI and TCIId alone or combined as mixed infections. Other T. cruzi genotypes (TCIIb and TCIIe) have not yet been detected.

\section{Anatomical and pathological study of the placentas}

The membranes were complete in 22 cases; the umbilical cord measured an average of $31.2 \mathrm{~cm}$ with a range from 8.5 to $58 \mathrm{~cm}$; mean diameter of the cord was $1.4 \mathrm{~cm}$ (range 0.5 $1.8 \mathrm{~cm}$ ). The insertion of the cord was paracentral in 21 cases, marginal in 4, central in three and had an eccentric location in one case. Three of the cases had membranes with scarred lesions, two had edema and one had a lesion with imprecise border. Microscopic examination demonstrated edema, necrosis, fibrinoid deposit and slight lymphoplasmatic infiltration in 29 placentas. We found erythroblastosis in three placentas, in one of which we found amastigotes of $T$. cruzi (one of the neonates with congenital infection). In three cases the immunohistological study demonstrated a decrease in actine expression in the trophoblast cells (Fig. 1). In the placentas of the non-Chagasic mothers there were no differences with the placentas of the Chagasic mothers, with the exception of erythroblastosis and amastigotes forms that were present only in the latter group where the lymphoplasmatic infiltration was more intense then in the normal placentas.

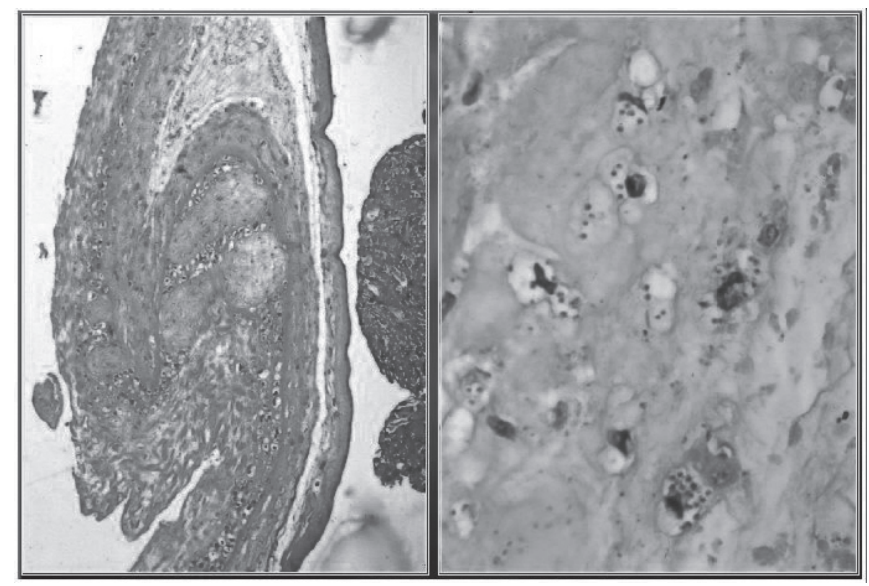

Fig. 1a: Placenta membranes with inflamation and parasites in the cytoplasm of macrophages. Hematoxiline \& Eosine 40x.

Fig. 1b: Placenta membranes with inflamation and parasites in the cytoplasm of macrophages. Hematoxiline \& Eosine 200x.

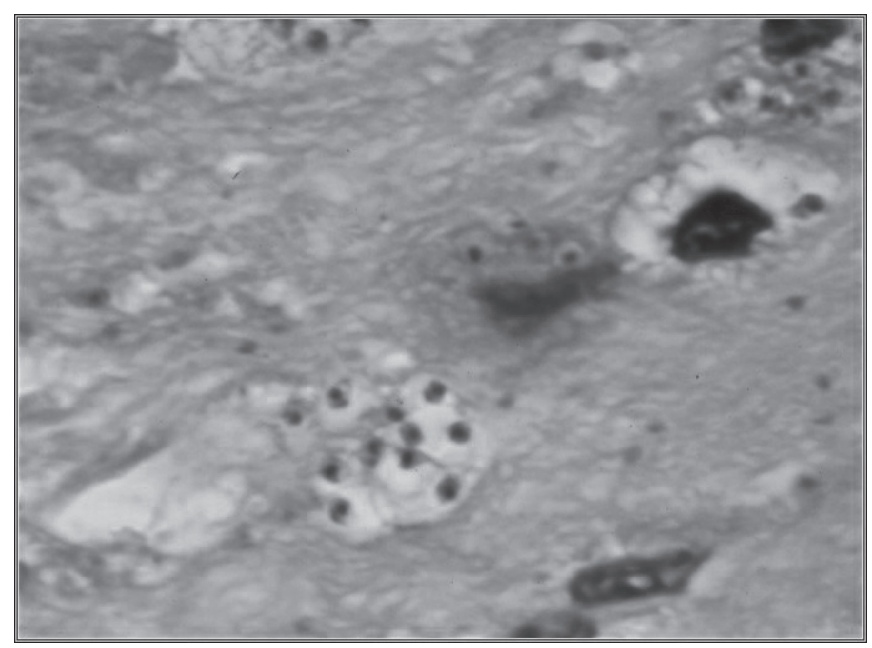

Fig. 2: Macrophages with parasites in the cytoplasm Hematoxiline \& Eosine 1000x. 


\section{DISCUSSION}

The prevalence of Chagas infection in the general population of the endemic zones of Chile has decreased notably in the last two decades, due principally to the success of the Program of Vector Control (Moncayo, 2003). This reduction in seropositive cases of the general public has also been favored by the housing policy developed in rural areas of Chile, which has produced important advances in groups of people who had grave housing deficiencies (materials or health conditions) (Mideplan, 1998). Rural subsidies have reduced this percentage from $16.7 \%$ in 1990 to $9.9 \%$ in 1998 (Mideplan, 2000). Between 1992 and 2002 the percentage of rural houses with electricity increased from $54 \%$ to $79 \%$ (CNE, 2003). Finally, the level of education has played an important role in the decrease in the incidence of Chagas disease. In 1904, 49.7\% of the population of Chile was analphabetic, while the 2002 census indicated only $4.3 \%$. In the IV Region, of a total of 68,277 inhabitants 10 years or older, there are about 5,582 analphabetic persons; in other words, $91.82 \%$ of the inhabitants know how to read and write (INE, 2003). However, these advances are not indispensable to avoid the congenital transmission of $T$. cruzi, which is a pressing public health problem in countries of the Southern Cone (Carlier and Torrico, 2003). Since there is not yet a ministerial norm for the study of congenital transmission in Chile, in order to establish appropriate actions of intervention and control it is indispensable to know the current prevalence of Chagas infection in pregnant women, especially among those who live in endemic areas and are known to be at risk because they have been in contact with the domestic vector (vinchuca) or report having been bitten by this insect. Previous studies of infected women have shown the prevalence in urban and rural areas of Latin American countries to vary between $2 \%$ and 51\% (WHO, 1991); yearly cases of congenital infection by T. cruzi have been estimated at 1500 (Carlier, 2007), with rates from 112\% (Virreira et al., 2006).

Preliminary studies of the prevalence of infection of pregnant women in the IV Region of Chile found $33.1 \%$ (Lorca et al., 1987), 15.6\% (Aguilera et al., 1988) and $7.8 \%$ (García et al., 2001). Our study found a prevalence of $3.7 \%$ in the Province of Choapa, IV Region, for the period 2005-2008. Since pregnancy is considered as a physiological state, these percentages of the prevalence of Chagas disease in pregnant women, considering the range of fertility to be from 15 to 49 years (INE, 2003), are similar to that of the general population in this age range. The preliminary estimation of congenital transmission of T. cruzi $(2.5 \%)$ is similar to estimates in the international literature (Howard, 1962; Muñoz et al., 1992; Carlier and Torrico, 2003; Gürtier et al., 2003; Torrico et al., 2004). The current information on maternal infection, congenital transmission and fertility in the Province of Choapa will allow prediction of the cases expected for the region, and thus establishment of adequate protocols of diagnosis and treatment, which is the purpose of this pilot project.

The information gathered up to now about T. cruzi genotypes found in the mothers indicates that the TCI is one of the most represented, suggesting that this lineage is probably transmitted to newborns, in contrast to Bolivia and
Argentina where most vertical transmissions are only TCIId genotypes (Virreyra et al., 2006; Corrales et al., 2009).

A number of authors have suggested that congenital Chagas disease requires a multidisciplinary approach within the family group. The prevalence of congenital transmission in siblings of infected newborns in Salta, Argentina was $31.4 \%$ (32 of 102 children), while no infected siblings were found in families without congenital cases. In four of these cases two generations of transmission were documented (grandmother to mother and mother to newborn), thus it was recommended to test siblings of infected neonates even if they are asymptomatic (Sánchez et al., 2005). Our study confirmed the importance of a family epidemiological study. As expected, the maternal grandmothers had a high percentage of infection $(74.3 \%)$, since they acquired the disease in an epoch when there was not an adequate control of parasitosis. We are currently studying T. cruzi infection in siblings of mothers with Chagas disease whose offspring were born in the period 2005-2008.

The study of placentas allowed us to demonstrate that the infection by $T$. cruzi induces the depletion of microfilaments in the syncytrophotoblast of the human placenta and is associated with premature birth, spontaneous abortion and placentitis. The parasite has been found especially in the corionic fibroblasts and in the subamniotic mesenchyme of the marginal cavity where the membranes attach to the corionic plate. Since we did not observe signs of villitis or lesions of the intervellitis, we suggest that the passage of parasites from the mother is by the corionic route, without direct invasion of the trophoblast (Sartori et al., 2003). Mjihdi et al. (2002) observed that placentas infected with $T$. cruzi contained inflammatory infiltrations and developed ischemic necrosis, deposits of fibrin and vascular thrombosis. Morphological alterations due to chronic and acute infection have been described principally in extraplacental areas, both at the level of optical microscopy and ultrastructure (Oddo et al., 1992; Labarca et al., 1992; Solari et al., 1993). In our observations, the macroscopic microscopic alterations observed without congenital transmission of $T$. cruzi were notable. In one placenta with erythroblastosis, we demonstrated the presence of amastigote forms of the parasite, which coincided with the congenital infection of the newborn. The decrease of the actine expression in the trophoblast cells has been interpreted as a diminishing and reorganization of the microfilaments of the cytokelet by the earlier action of T.cruzi in the vertical transmission. The evaluation of the diagnostic and control protocols generated will allow in the future evaluating whether it has been possible to modify the natural history of the vertical transmission of $T$. cruzi in Chile according to the international recommendations for our endemic zones (OPS, 2004).

\section{ACKNOWLEDGEMENTS}

This work was supported by Grant 1080445 from Fondo Nacional de Desarrollo Científico y Tecnológico (FONDECYT-Chile), DI-SAL 05/17-2 from the University of Chile and Project 06/09 Valona Region, Belgium. The authors thank Dr. Juan Diego Maya of the Pharmacological Program of the Institute of Biomedical Sciences for providing 
us with the epimastigote forms of Trypanosoma cruzi, M. Isabel Jercic, medical technologist of the Reference Laboratory of the Public Health Institute for performing the ELISA study of neonate children of mothers with Chagas disease. A special thanks to all the health personnel of hospitals, rural outposts and clinics of the Province of Choapa, IV Region, Chile.

\section{REFERENCES}

AGUILERA $X$, APT $W$, REYES H, SANDOVAL J, SALGADO R, CARRANZA G, PIQUERAS E, REYES J, CORRAL, G (1988). Enfermedad de Chagas congénita: estudio prospectivo en dos localidades hiperendémicas de la IV Región de Chile. Parasitol al Día, 12: 19-25.

APT, W, REYES, H (1986). Aspectos epidemiológicos de la enfermedad de Chagas en Chile. Distribución geográfica, índices de infección en vectores y en humanos. Parasitol al Día, 10: 94-101.

APT W, HEITMANN I, JERSIC I, JOFRÉ L, MUÑOZ CASAS DEL VALLE P, NOEMÍ I, SAN MARTÍN AM, SAPUNAR J, TORRES M, ZULANTAY I (2008). Guidelines for Chagas disease: Part V. Laboratory Diagnosis of Chagas Disease. Rev Chil Infectol, 25(5): 380-383.

BENÍTEZ A (1994) Características climáticas y geológicas de Chile. En: G. Espinoza, P Pisani, L Contreras \& P. Camus (eds). Perfil ambiental de Chile: 19-37. Comisión Nacional del Medio Ambiente, Santiago, Chile.

CARLIER Y (2007). Congenital Chagas disease: from the laboratory to public health. Bull Mem Acad R Med Belg, 162 (7-9): 409-416.

CARLIER Y, TORRICO F (2003). Congenital infection with Trypanosoma cruzi: from mechanisms of transmission to strategies for diagnosis and control. Rev Soc Bras Med Trop, 36(6): 767-771.

CNE. (2003). Comisión Nacional de Energía. La electrificación rural en Chile. Gobierno de Chile. 1992-2002. 16 páginas.

CORREA V, ZUNIGA J, CONTRERAS MC, VALDES JC, ROJAS A, VILLARROEL F, SCHENONE H (1984). Epidemiología de la enfermedad de Chagas en Chile. Sectores rurales. Infestación domiciliaria por triatominos, tasas de infección de estos por Trypanosoma cruzi y nuevos aportes al conocimiento de la infección chagásica en mamíferos domésticos de la IV Región (1982-1983). Bol Chil Parasitol, 39: 24-27.

CORRALES RM, MORA MC, NEGRETTE OS, DIOSQUE P, LACUNZA D, VIRREIRA M, BRENIÈRE SF, BASOMBRIO MA (2009). Congenital Chagas disease involves Trypanosoma cruzi sub-lineage IId in the northwestern province of Salta, Argentina. Infect Genet Evol., 9(2): 278-82.

FREILIJ H, MÜLLER L, GONZÁLEZ CAPPA ME (1982). Direct Micromethod for Diagnosis of Acute and Congenital Chagas'Disease. J Clin Microbiol, 18 (2): 327-330.

GALUPPO S, BACIGALUPO A, GARCÍA A, ORTIZ S, CORONADO X, CATTAN PE, SOLARI A (2009). Predominante of Trypanosoma cruzi genotypes in two reservoirs infected by sylvatic Triatoma infestans of an endemic area of Chile. Acta Trop, 111(1): 90-3.

GARCÍA A, BAHAMONDE MI, VERDUGO S, CORREA C, SOLARI A, TASSARA R, LORCA M (2001). Infección transplacentaria por Trypanosoma cruzi en Chile. Rev Med Chile, 129: 330-332.

GÜRTLER RE, SEGURA EL, COHEN JE 2003. Congenital transmission of Trypanosoma cruzi infection in Argentina. Emerg Infect Dis, 9(1): 2932.

HOWARD JE. 1962. La enfermedad de Chagas congénita. Colección de Monografías. Universidad de Chile. Santiago.

INE (2003). Censo de Población 2002. Síntesis de Resultados. Editores La Nación. 139 páginas.

LABARCA J, ACUÑA G, SAAVEDRA H, ODDÓ D, SEPÚLVEDA C, BALLESTEROS J, ALVAREZ M (1992). Chagas disease with the acquired immunodeficiency síndrome. Clinical case. Rev Med Chil., 120(2): 174-9.

LORCA M, BEROÍZA AM, MUÑOZ P, GUAJARDO U, SILVA J, CANALES M, ATIAS A (1987). Estudio materno infantil de enfermedad de Chagas en zonas endémicas. III: Salamanca, Valle del Choapa, Chile. Parasitol al Día, 11: 97-100.

MIDEPLAN. Ministerio de Planificación y Cooperación. (1999). Documento 1992-1998. Encuesta CASEN.
MIDEPLAN. Ministerio de Planificación y Cooperación. (2001). Situación del Sector Rural en Chile 2000. Documento N ${ }^{\circ}$ 7. Gobierno de Chile.

MJIHDI A, LAMBOT MA, STEWART IJ, DETOURNAY O, NOEL JC, CARLIER Y, TRUYENS C. (2002). Acute Trypanosoma cruzi infection in mouse induces infertility or placental parasite invasion and ischemic necrosis associated with massive fetal loss. Am J Pathol, 161(2): 673-80.

MUÑOZ P, THIERMANN E, ATÍAS A, ACEVEDO C (1992). Enfermedad de Chagas congénita sintomática en recién nacidos y lactantes. Bol Chil Ped, 63 (4): 196-202.

MONCAYO A (2003). Chagas disease: Current Epidemiological Trends after the Interruption of Vectorial and Transfusional Transmission in the Southern Cone Countries. Mem Inst Oswaldo Cruz, 92(1): 577-591.

ODDO D, CASANOVA M, ACUÑA G, BALLESTEROS J, MORALES B (1992). Acute Chagas' disease (Trypanosomiasis americana) in acquired immunodeficiency syndrome: Report of two cases. Hum Pathol, 23: 41-4

OPS (2004). Consulta sobre la Enfermedad de Chagas Congénita, su epidemiología y manejo. Montevideo, Uruguay. 301/04.

OPS/OMS (2003). XII ${ }^{a}$ Reunión de la Comisión Intergubernamental del Cono Sur para la eliminación de Triatoma infestans y la interrupción de la transmisión transfusional de la Tripanosomiasis Americana (INCOSUR/Chagas). Santiago, Chile: World Health Organization.

RÍOS A, ALCAÍNO H, APT W (1986). Enfermedad de Chagas en caninos, bovinos y équidos sinantrópicos de la Provincia del Limarí, Chile. Parasitol al Día, 10: 40-45.

WHO (1991). Control of Chagas disease. Report of a WHO Expert Committee. Technical Report Series WHO/RSD/91.811.

WHO (2000). Chagas Disease interrupted in Chile. TDR News. 61: 10.

WHO (2002).Control of Chagas Disease. WHO Technical Report Series $\mathrm{N}^{\circ}$ 905, Geneva.

SALAZAR JP, OLGUÍN F, OLIVERA E, APT W, GIL LC, LILLO R, SANDOVAL L, CASTILLO D, AGUILERA P, PARRA M, AGUILERA J, ZULANTAY I 2006. Enfermedad de Chagas crónica en Chile. Experiencia de intervención educativa. Parasitolol Latinoam 61: 94-97.

SÁNCHEZ O, MORA MC, BASOMBRIO MA (2005). High prevalence of congenital Trypanosoma cruzi infection and family clustering in Salta, Argentina. Pediatrics, 115(6): 668-672.

SARTORI MJ, MEZZANO L, FABRO SP (2003). Trypanosoma cruzi infection induces microfilament depletion in human placenta syncytiotrophoblast. Placenta, 24(7): 767-771.

SCHENONE H, CONTRERAS MC, SOLARI A, GARCÍA A, ROJAS A, LORCA, M. 2003. Tratamiento con Nifurtimox de la infección chagásica crónica en niños. Rev Med Chile, 131: 1089-1090.

SOLARI A, CAMPILLAY R, ORTIZ S, WALLACE A 2001a. Identification of Trypanosoma cruzi genotypes circulating in Chilean chagasic patients. Exp Parasitol, 97: 226-233.

SOLARI A, ORTIZ S, SOTO A, ARANCIBIA C, CAMPILLAY R, CONTRERAS M.C, SALINAS P, ROJAS A, SCHENONE H (2001b). Treatment of Trypanosoma cruzi-infected children with nifurtimox: a 3 year follow-up by PCR. J Antimicr Chemother, 48: 515-519.

SOLARI A, SAAVEDRA H, SEPÚLVEDA C, ODDO D, ACUÑA G, LABARCA J, MUÑOZ S, CUNY G, BRENGUES C, VEAS F (1993). Successful treatment of Trypanosoma cruzi encephalitis in a patient with hemophilia and AIDS. Clin Infect Dis, 16: 255-259.

TORRICO F, ALONSO-VEGA C, SUAREZ E, RODRIGUEZ P, TORRICO MC, DRAMAIX M, TRUYENS C, CARLIER Y (2004). Maternal Trypanosoma cruzi infection, pregnancy outcome, morbidity, and mortality of congenitally infected and non-infected newborns in Bolivia. Am J Trop Med Hyg, 70(2): 201-9.

VEAS F, CUNY G, BRENIERE SF, TIBAYRENC M (1991). Subspecific kDNA probes for major clones of Trypanosoma cruzi. Acta Trop, 48: 79-82.

VIRREIRA M, TORRICO F, TRUYENS C, ALONSO-VEGA C, SOLANO M, CARLIER Y, SVOBODA M (2003). Comparison of Polymerase Chain Reaction methods for reliable and easy detection of congenital Trypanosoma cruzi infection. Am J Trop Med Hyg 68 (5): 574-582.

VIRREIRA M, ALONSO-VEGA C, SOLANO M, JIJENA J, BRUTUS L, BUSTAMANTE $Z$, TRUYENS C, SCHENEIDER D, TORRICO F, CARLIER Y, SVOBODA M (2006). Congenital Chagas disease in Bolivia is not associated with DNA polymorphism of Trypanosoma cruzi. Am J Trop Med Hyg, 75 (5): 871-879.

ZULANTAY I, APT W, RODRÍGUEZ J, VENEGAS J, SÁNCHEZ G (1998). Serologic evaluation of treatment of chronic Chagas disease with allopurinol and itraconazole. Rev Med Chil, 126(3): 265-70. 
ZULANTAY I., HONORES P., SOLARI A., APT W., ORTIZ S., OSUNA A., ROJAS A., LÓPEZ B. and SÁNCHEZ G. (2004). Use of polymerase chain reaction (PCR) and hybridization assays to detect Trypanosoma cruzi in chronic chagasic patients treated with itraconazole or allopurinol. Diagn Microbiol Infect Dis, 48 (4): 253257.
ZULANTAY I, APT W, ROCHA C, SOLARI A, OSUNA A, SÁNCHEZ G, GIL L, MUNDACA K, VENEGAS J, ROJAS A, RODRÍGUEZ J, APT W (2007). The PCR-based detection of Trypanosoma cruzi in the faeces of Triatoma infestans fed on patients with chronic American trypanosomiasis gives higher sensitivity and a quicker result than routine xenodiagnosis. Ann Trop Med Parasit, 101 (8): 673-679. 